\title{
INHALT
}

\section{H. FiedleR}

Untersuchungen zur Wirkungsweise ökonomischer Wachstumsfaktoren im Reproduktionsprozeß der Zierpflanzenproduktion - Ergebnisse der Schätzung aggregierter Produktionsfunktionen auf der Basis von

Betriebsdaten . . . . . . .

\section{P. RichteR}

Die Definition des Vermehrungskoeffizienten und seine Anwendung in Form einer Matrix in der Tulpenvermehrung (Kurzmittlg.) . . . .

H. Bochow und G. MENDE

Fragen des rationellen Einsatzes von Dazomet und Vapam zur chemischen Bodendesinfektion . . . . . . .

M. Hertneck und W. Fiedler

Untersuchungen über die Stippigkeit beim Apfel

1. Mittlg.

\section{Katzfuss}

${ }^{14} \mathrm{CO}_{2}$-Assimilation von Blättern zweier Apfelsorten im Verlaufe der natürlichen Alterung . . . . . . .

\section{J. REINHOLD}

Ein Beitrag zu Möglichkeiten der Steuerung von biotechnischen Umwandlungsprozessen dicht gelagerter, wasserreicher organogener Abprodukte und Abfälle - dargestellt am Beispiel fester Fäkalstoffe aus der industriemäßigen Tierproduktion

\section{СОДЕРЖАНІІЕ}

\section{Х. ФИДлЕР}

Изучение әкономических факторов роста в процессе воспроизводства в цветоводстве. - Результаты оценки агрегированных производственных функций на основе данных хозйств . . . . . .

\section{П. Рихтер}

Определение коэффициента размножения и его применение в проводстве тюльпанов

\section{Х. Бохов, Г. Менде}

Вопросы рационального использования дазомета и вапама для химической дезинфекции почвы

М. ХертHEК, В. Фидлер

Изучение горькой ямчатости яблони.

I-ое сообщение: Симптоматология и характеристика объема поражения горькой ямчатостью . . . .

\section{M. КАтц $\oplus$ YC}

Ассимиляция $\mathrm{CO}_{2}\left(\mathrm{C} \mathrm{C}^{14}\right)$ листьями двух сортов яблони в течение естественного процесса старения

\section{Ю. РАЙнхольД}

О возможностях управления биотехническими процессами превращения уплотненных органогенных отходов и оторросов с высоким содержанием влаги на примере твердых фекальных веществ, накапливающихся в животноводческих комплексах промышленного типа .

\section{CONTENTS}

\section{H. FIEDLER}

Studies on the mode of action of economic growth factors in the reproduction process of ornamental plant production - Results of the estimation of aggregated production functions on the basis of data from 


\section{P. RICHTER}

Definition of the propagation coefficient and its use as a matrix in tulip propagation (Brief information)

H. Bochow and G. Mende

Problems regarding the efficient use of Dazomet and Vapam for chemical soil disinfection . . . . . . . .

M. Hertineck and W. Fiedler

Studies on bitter pit of apple. I. Symptoms and characterization of the extent of bitter pit . . . . . 247

\section{KATZFUSS}

${ }^{14} \mathrm{CO}_{2}$ assimilation of the leaves of two apple varieties during natural ageing . . . . . . . . 257

J. REINHOLD

On possibilities of controlling biotechnical decomposition processes in densely stratified by- and waste products of high water content, demonstrated by the example of solid fecal matter from industry-like livestock units . . . . . . . . . 265 
